disasters be invested in strengthening preparedness. ${ }^{8}$ Much expertise exists in this field, and programmes like the Leaders courses can enhance capacity to develop disaster reduction programmes by increasing strategic management, leadership, and analytical skills of the participants. ${ }^{9}$ Governments in Latin America now help their neighbours when they are hit by hurricanes and other natural disasters. Similar capacity is urgently needed in other parts of the world.

Disasters undermine and reverse development, particularly in fragile states, where some indicators for the millennium development goals are in decline. ${ }^{10}$ Adequate funding is needed to make progress and we should encourage donor countries to achieve the Monterrey consensus of providing $0.7 \%$ of their gross domestic product as development aid to the poorest countries. ${ }^{11}$ New ways must be found to coordinate and invest development and humanitarian funds in fragile states, so that communities at risk can receive adequate support to improve their livelihoods and reduce their vulnerabilities.

\title{
WHO response to tsunami
}

The immediate WHO response to the tsunami was to help local authorities in the provision of life saving care, mobilising supplies, and assessing health needs (www.who.int/tsunami/en/). Within three weeks, 120 staff were moved into the region and medical supplies for two million people and cholera kits for a million more were sent to the affected countries. The priorities for action were:

- Early warning, surveillance, and response to communicable disease (especially malaria, diarrhoea, dengue, and tetanus). This was in place by day 10 of the crisis, providing daily epidemiological updates in partnership with the Global Outbreak Alert and Response Network ${ }^{6}$

- Develop and act on public health strategies-priority to be given to water, nutrition, sanitation, immunisation, environmental and mental health, and women's health

- Ensure access to dependable health services-more than $70 \%$ of the target areas are now assessed and supported

- Sustain an effective health system supply chain-logisticians are deployed and systems developed in about $70 \%$ of the target areas

- Coordination of all health actors-functioning in about $85 \%$ of locations

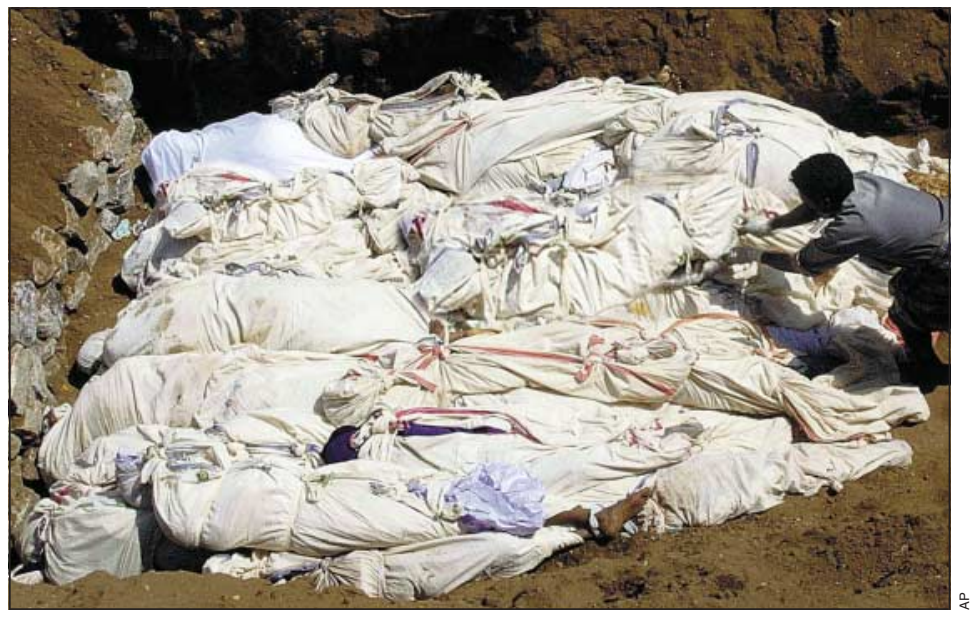

Mass burial immediately after the tsunami diverted resources from more urgent needs

This tsunami hit the poor the hardest. The impact of disasters reflects the way societies choose their priorities and allocate their resources. The choices of the international community can substantially reduce the risks and impact of such disasters.

Competing interests: WHO's humanitarian programmes are largely financed through extrabudgetary funds.

Walker P, Wisner B, Leaning J, Minear L. Smoke and mirrors: deficiencies in disaster funding. BMJ 2005;330:247-50.

De Ville de Goyet C. Stop propagating disaster myths. Lancet 2000;356:762-4.

3 World Health Organization. Flooding and communicable diseases fact sheet. www.who.int/hac/techguidance/ems/flood cds/en/ (accessed 19 Jan 2005).

4 Benson C, Twigg J. Measuring mitigation; methodologies for assessing natural hazard risks and the net benefits of mitigation. Geneva: ProVention Consortium, 2004. www.proventionconsortium.org/files/measuring mitigation/Measuring Mitigation report.pdf (accessed 18 Jan 2004).

5 Principles and good practice of humanitarian donorship. International meeting on good humanitarian donorship. Stockholm, 16-17 June 2003. www.odi.org.uk/hpg/papers/

Good\%20Humanitarian\%20Donorship\%20Stockholm.pdf (accessed 19 Jan 2005).

6 Global Outbreak Alert and Response Network. www.who.int/csr/ outbreaknetwork/en/ (accessed 6 Jan 2005).

7 Twigg J. Disaster risk reduction: mitigation and preparedness in development and emergency programming. London: Humanitarian Practice Network, Overseas Development Institute, 2004. (Good practice review No 9.)

8 Egeland J. Speech at World Conference on Disaster Reduction, Kobe, Japan, 18-22 January 2005. www.unisdr.org/wcdr/ (accessed 19 Jan Japan,

9 Pan American Health Organisation. Disasters and humanitarian assistance. Pan American Health Organisation. Disasters and humanitarian assi.
www.paho.org/english/dd/ped/home.htm (accessed 18 Jan 2005).

10 High Level Forum on the Millennium Development Goals. Achieving the millennium development goals in fragile states. Background paper to 2nd meeting Abuja, Nigeria, December 2-3, 2004. www.hlfhealthmdgs.org/ Documents/FragileStates.pdf (accessed 18 Jan 2005).

11 Sachs JD. Health in the developing world: achieving the millennium development goals. Bull World Health Organ 2004;82:947-52.

\section{A teacher remembered: Gerald Tresidder}

Gerald Tresidder, consultant urological surgeon and anatomy teacher at The London Hospital, Whitechapel, taught me one of the most memorable lessons I received during clinical training. He was a devoted anatomy teacher, as well as a urologist, and in 1974 was very dismayed when none of our fifth year student group attended an ileal conduit operation he had performed on a patient with bladder carcinoma.

At our next teaching session, he expressed his disappointment and asked why we were not interested. Nobody volunteered, and so I said that very few, if any of us, felt we were going to be urologists and that a long technical operation therefore held little interest. Gerald replied that if we were going to be urologists he was not worried in the slightest whether we attended, since we would see many such operations during our urology training. However, since most of us were going to practise in other specialties, particularly general practice, an understanding of the operation and its complications might one day prove important. I realised that he was right, and for once remained silent.

Kieran J Moriarty consultant physician and gastroenterologist, Royal Bolton Hospital, Bolton (Kieran.Moriarty@boltonh-tr.nwest.nhs.uk) 